\title{
FAKTOR-FAKTOR YANG DOMINAN MEMPENGARUHI KEPUASAN PASIEN RAWAT INAP PADA RUMAH SAKIT UMUM BINA KASIH MEDAN
}

\author{
Laura Lintresa1, Esli Silalahi², Saut Purba ${ }^{3}$ \\ 1,2,3 Universitas Katolik Santo Thomas Medan Jl. Setia Budi No. 479F, 20132, Indonesia \\ Email : saut_purba@ust.ac.id
}

\begin{abstract}
This study aims to determine the dominant factors affecting the satisfaction of BPJS inpatients. The study population was 1732 BPJS patients who were hospitalized in June-July 2019. The research sample consisted of 70 patients. The data collection techniques used were documentation and questionnaires. The data obtained were analyzed by factor analysis. Based on the results of the study, it was concluded that the most dominant factors affecting the satisfaction of inpatients at the Bina Kasih General Hospital in Medan were performance factors, additional features, endurance, reliability, responsiveness, assurance, empathy, infrastructure, situation description, social environment, controlling emotions. , price levels, payment terms, service fees. Of the fourteen indicators, it can be seen that the service cost factor must be considered by the hospital because this factor is the complaint of patients at the Bina Kasih General Hospital in Medan.
\end{abstract}

Keywords: Factor analysis, inpatient satisfaction

\section{PENDAHULUAN}

Rumah sakit merupakan salah satu jenis perusahaan jasa dimana perusahaan jasa yang ingin berkembang dan mendapatkan keunggulan kompetitif harus dapat memberikan kualitas pelayanan yang baik kepada para pelanggan. Selain itu rumah sakit juga harus memperhatikan nilai pelanggan dan keunggulan produk guna dapat bertahan dalam iklim persaingan yang sangat ketat. Perjuangan untuk menciptakan bisnis yang berulang dengan pelanggan menempati titik sentral dalam upaya rumah sakit untuk tetap unggul pada persaingan jangka panjang.

Pelayanan prima merupakan elemen utama pada Rumah Sakit dan unit kesehatan. Rumah sakit dituntut untuk memberikan pẹlayanan kesehatan yang memenuhi standar pelayanan yang optimal. Hal tersebut sebagai akuntabilitas rumah sakit supaya mampu bersaing dengan rumah sakit lainnya. Hakikat dasar dari Rumah Sakit adalah pemenuhan kebutuhan dan tuntutan pasien yang mengharapkan penyelesaian masalah kesehatannya pada rumah sakit. Pasien memandang bahwa hanya rumah sakit yang mampu memberikan pelayanan medis sebagai upaya penyembuhan dan pemulihan atas rasa sakit yang dideritanya. Pasien mengharapkan pelayanan yang siap, cepat, tanggap dan nyaman terhadap keluhan penyakit pasien.

Kepuasan pasien tergantung pada kualitas pelayanan, pelayanan adalah semua upaya yang dilakukan karyawan untuk memenuhi keinginan pelanggannya dengan jasa yang akan diberikan. Suatu pelayanan dikatakan baik oleh pasien, ditentukan oleh kenyataan apakah jasa yang diberikan bisa memenuhi kebutuhan pasien, dengan menggunakan persepsi pasien tentang pelayanan yang diterima (memuaskan atau mengecewakan, juga termasuk lamanya waktu pelayanan). Kepuasan dimulai dari penerimaan terhadap pasien dari pertama kali datang, sampai pasien meninggalkan rumah sakit. Kepuasan adalah tingkat perasaan seseorang setelah membandingkan kinerja atau hasil yang dirasakan. Kunci keberhasilan pengelola perusahaan jasa tergantung pada kualitas pelayanan yang diberikan kepada pasien/pelanggannya. Ketidakpuasan pasien diartikan sama dengan keluhan terhadap rumah sakit, seperti pelayanan yang dilakukan oleh (1). Tenaga kesehatannya (dokter, 
perawat, apoteker, dan lainnya); (2). Struktur sistem perawatan kesehatan (biaya, sistem asuransi, kemampuan dan prasarana pusat kesehatan dan lain-lain) yang tidak memuaskan. Pasien mengharapkan interaksi yang baik, sopan, ramah, nyaman dengan tenaga kesehatan, serta kompetensi, kualifikasi dan kepribadian yang baik dari pelayanan kesehatan.

Pada akhir-akhir ini terlihat bahwa rumah sakit terus berkembang, baik dalam jumlah, kapasitas maupun sarana prasarana seiring dengan perkembangan tehnologi. Walaupun terdapat perkembangan rumah sakit dari waktu ke waktu, tetapi fungsi dasar suatu rumah sakit tetap tidak berubah. Fungsi dasar suatu rumah sakit adalah pemulihan kesehatan anggota masyarakat, baik secara pelayanan rawat inap. maupun rawat jalan, serta konsultasi pemeliharaan atau perawatan kesehatan anggota masyarakat. Rumah sakit merupakan suatu tempat pelayanan, yang menyelenggarakan pelayanan medik dan spesialistik, pelayanan penunjang medik, pelayanan instalasi medik dan pelayanan perawatan secara rawat jalan dan rawat inap, Kuncoro (dalam Irsansyah Putra 2013)

Rumah Sakit Umum Bina Kasih Medan merupakan perusahaan yang bergerak dibidang pelayanan jasa di Kotamadya Medan.Rumah Sakit Umum Bina Kasih Medan berlokasi di Jalan Jend. TB Simatupang No.148 Medan Sunggal, Sumatera Utara. Rumah Sakit Umum Bina Kasih Medan memiliki dokter profesional dibidangnya masing-masing, begitu juga perawat, ruang rawat inap, penerangan yang memadai, peralatan yang lengkap dan modern, lingkungan yang bersih, penanganan dan keluhan pasien secara cepat dan tepat waktu serta tempat parkir yang luas.

Rumah sakit ini menerima pasien rawat inap dan pasien rawat jalan (Pasien Umum dan Pasien BPJS) dan penelitian ini hanya menfokuskan pada pasien BPJS rawat inap. Pasien BPJS rawat inap pada Rumah Sakit Umum Bina Kasih Medan tahun 2017 berjumlah 11.489 orang dan tahun 2018 berjumlah 10.573 orang, terdapat penurunan di tahun 2018.

Beberapa penelitian yang berkaitan dengan topik ini, Martini Widi Lestari (2015), meneliti tentang ,Analisis Faktor-faktor yang Mempengaruhi Kepuasan Pasien Rawat Inap di RSUD Kabupaten Buleleng. Hasil penelitian menunjukkan bahwa faktor yang mempengaruhi kepuasan pasien adalah faktor biaya, pengalaman, kualitas produk, image/citra, sedangkan faktor yang dominan mempengaruhi kepuasan pasien adalah faktor biaya.

Duffy \& Alice A. Ketchand dalam Nirsetyo Wahdi (2006) telah meneliti pada 206 manula penghuni wredha (panti jompo), mereka mewakili dari $90 \%$ populasi penghuni dari 10 panti wredha yang kemampuan kognitifnya masih baik. Hasil penelitian ini menunjukkan bahwa perumusan hasil system pelayanan yaitu mutu layanan sebagai faktor yang menentukan kepuasan konsumen masih belum lengkap. Dalam penelitian tersebut ditemukan bahwa ada variable lain, yaitu kesejahteraan/kondisi konsumen, yang juga berpengaruh signifikan pada kepuasan konsumen. Selain itu, kesejahteraan/kondisi konsumen tersebut juga sangat dipengaruhi oleh mod/suasana hati.

Sedangkan P. Mardeen Atkins, Brenda Stevenson M., dkk (dalam Nirsetyo Wahdi 2006) juga meneliti adanya korelasi antara kepuasan perawatan yang menimbulkan minat pasien untuk kembali berobat dan keinginan mereka untuk merekomendasikan pelayanan rumah sakit pada teman dan keluarga. Kenyataannya, pelayanan perawatan secara konsisten berperan sebagai faktor penentu kepuasan pasien untuk selajutnya dijadikan sinyal atau tanda tentang pentingnya mengembangkan strategi pengawasan tingkat kepuasan pekerja bagi marketer. Dalam penelitian tersebut dapat disimpulkan bahwa kualitas pelayanan para perawat rumah sakit mempunyai hubungan yang kuat terhadap kepuasan pasien.

Begitu juga halnya penelitian Nindia Nilaikan (2012), menunjukkan bahwa faktor yang mempengaruhi kepuasan pelayanan kesehatan pasien rawat inap adalah keandalan (reliability) yang dilihat dari konsistensi kerja perawat dan kemampuan kerja yang dapat 
dipercaya, ketanggapan (responsiveness) yaitu sikap tanggap para karyawan rumah sakit melayani saat dibutuhkan pasien, kepedulian (emphaty) yaitu kemudahan perawat dalam melakukan hubungan komunikasi yang baik dengan pasien, jaminan (assurance) yaitu bebas bahaya, resiko dan keragu-raguan, dan keberwujudan (tangibles) yang terlihat fasilitas fisik, perlengkapan dan material yang tersedia lengkap.

Penelitian ini menganalisis faktor-faktor dominan yang mempengaruhi kepuasan pasien rawat inap pada rumah sakit umum Bina Kasih Medan. Adapun yang mendasari penelitian ini adalah untuk mengetahui faktor apa yang lebih dominan mempengaruhi kepuasan pasien. Hal ini penting sebagai evaluasi terhadap strategi pemasaran dan peningkatan kualitas pelayanan yang dijalankan oleh pihak Rumah Sakit.

\section{Pengertian Pemasaran Jasa}

\section{TINJAUAN PUSTAKA}

Di dalam pemasaran terdapat proses pertukaran dimana proses pertukaran ini memerlukan banyak tenaga dan keterampilan. Sehingga manajemen pemasaran terjadi bila setidaknya satu pihak dalam pertukaran potensial memikirkan sasaran dan cara mendapatkan tanggapan yang dikehendaki dari pihak lain.Untuk menjalankan proses pemasaran jasa dalam suatu perusahaan sangat diperlukan sejumlah upaya atau keterampilan penting. Perusahaan harus mampu merencanakan dan mengelola hubungan yang bermanfaat dengan pasar. Perusahaan juga harus mampu mempertahankan pelanggan yang sah didapatkan dan berusaha menambah jumlah pelanggan melalui berbagai macam pelayanan kepada pelanggan sehingga membantu perusahaan untuk mecapai tujuan.

Pemasaran jasa adalah setiap tindakan atau unjuk kerja yang ditawarkan oleh salah satu pihak ke pihak lain yang secara prinsip intangible dan tidak menyebabkan perpindahan kepemilikan apapun, (Lupiyoadi ,2001). Pemasaran jasa adalah pemasaran yang bersifat intangible dan immaterial dan dilakukan saat konsumen berhadapan dengan produsen. Rangkuty (2002),

Dari uraian di atas maka dapat disimpulkan bahwa pemasaran jasa adalah tindakan yang dilakukan oleh pihak penyedia jasa ke pihak lain yang berfokus pada transaksi, dimana pada prinsipnya tidak berwujud dan tidak menyebabkan perpindahan kepemilikan apapun..

\section{Kepuasan Pelanggan}

Banyak perusahaan menempatkan kepuasan konsumen sebagai prioritas puncak dengan meningkatkan komunikasi dan pengetahuan tentang konsumen. Menurut Creven (2002) kepuasan pelanggan merupakan pemahaman tentang kebutuhan dan keinginan para pelanggan melalui produk yang dihasilkannya. Kepuasan pelanggan adalah tingkat perasaan seseorang setelah membandingkan kinerja (atau hasil) yang dirasakan dengan harapannya, Kotler (2002). Dari penjelasan di atas maka dapat disimpulkan bahwa pengertian kepuasan pelanggan adalah kepuasan atas produk yang digunakan untuk memenuhi dan keinginannya. Produk yang berkualitas tinggi dengan harga yang relatif murah dan mudah diperoleh jika diperlukan, hal ini dapat memberikan kepuasan kepada para pelanggan untuk memenuhi kebutuhan dan keinginannya. Seorang pelanggan jika merasa puas dengan nilai yang diberikan, sangat besar kemungkinannya untuk menjadi pelanggan. Konsep kepuasan konsumen ditunjukkan gambar 1 . berikut ini. 


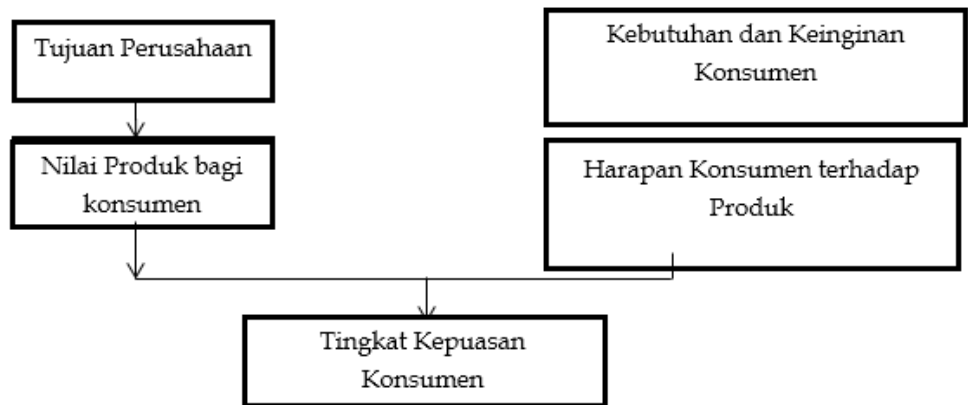

Gambar 1. Konsep Kepuasan Konsumen

Sumber: Kristanto, Paulus Liri. Psikologi Pemasaran. Cekatan Pertama,Jakarta, (Caps 2011)

\section{Aspek-aspek Kepuasan Pasien}

Aspek-aspek Kepuasan Pasien dapat diukur dari (a).Kenyamanan, aspek ini menggambarkan hal yang menyenangkan dalam semua kondisi, lokasi rumah sakit, kebersihan, kenyamanan ruangan, makanan dan minuman, peralatan ruangan, tata letak, penerangan, kebersihan WC/kamar mandi, pembuangan sampah, kesegaran ruangan, dan lain sebagainya.(b). Hubungan pasien dengan petugas Rumah Sakit, menggambarkan petugas yang mempunyai kepribadian baik yang mendukung jalannya pelayanan prima terjadi yang menyangkut keramahan, informasi yang diberikan, sejauh mana tingkat komunikasi, dukungan, tanggapan dokter/perawat di ruangan inap.(c). Kompetensi teknis petugas, menggambarkan mengenai keterampilan, pengetahuan dan kualifikasi petugas yang baik seperti kecepatan pelayanan pendaftaran, keterampilan dalam penggunaan teknologi, pengalaman petugas medis, gelar medis yang dimiliki terkenal, keberanian mengambil tindakan. (d). Biaya yang berkaitan dengan jumlah yang harus diberikan atas pelayanan yang telah didapatkan, seperti kewajaran biaya, kejelasan komponen biaya, biaya pelayanan, perbandingan dengan rumah sakit sejenis lainnya, tingkat masyarakat yang berobat ada tidaknya keringanan bagi masyarakat miskin.

Menurut Zeitham dan Berry (dalam Tjiptono; 2007), áspek-aspek kepuasan pasien meliputi: (a) Keistimewaan, yaitu dimana pasien merasa diperlukan secara istimewa oleh perawat selama proses pelayanan (b). Kesesuaian, yaitu sejauhmana pelayanan yang diberikan perawat sesuai dengan keinginan pasien, selain itu ada ketepatan waktu dan harga. (c). Estetika, yaitu dalam pelayanan berhubungan dengan kesesuaian tata letak barang maupun keindahan ruangan.

\section{Kualitas Pelayanan}

Kualitas adalah cara perusahaan jasa untuk tetap dapat unggul bersaing dalam memberikan jasa dengan kualitas yang lebih tinggi dari pesaingnya secara konsisten. Kualitas yang baik yang telah menjadi harapan dan impian bagi semua orang baik konsumen maupun produsen. Menurut Winston Dictionary (dalam Satrianegara; 2009), kualitas adalah tingkat kesempurnaan dari penampilan sesuatu yang sedang diamati. Kualitas menurut Goetsh \& Davis (dalam Yamit; 2005) adalah suatu kondisi dinamis yang berhubungan dengan produk, jasa, manusia, proses, dan lingkungan yang memenuhi atau melebihi harapan.

Berdasarkan beberapa pendapat tersebut dapat disimpulkan bahwa kualitas adalah kondisi dimana hasil dari produk dan jasa mencapai tingkat kesempurnaan yang sesuai dengan kebutuhan pasien, standar yang berlaku dan tujuan. Pelayanan adalah setiap kegiatan atau manfaat yang ditawarkan suatu pihak kepada pihak lain, yang pada dasarnya tidak berwujud atau tidak mengakibatkan kepemilikan apapun. 
Maka pengertian kualitas pelayanan adalah suatu tingkat layanan yang berhubungan dengan terpenuhinya harapan dan kebutuhan pelanggan atau penggunanya. Artinya pelayanan dikatakan berkualitas apabila perusahaan atau lembaga tertentu mampu menyediakan produk dan jasa (pelayanan) sesuai dengan keinginan, kebutuhan maupun harapan pelanggan/penggunanya.

\section{Faktor-faktor yang Mempengaruhi Kepuasan Pasien}

Menurut Budi Astuti (dalam Nooria; 2008), faktor yang mempengaruhi kepuasan pasien yaitu:

1) Kualitas produk atau jasa, pasien akan merasa puas bila hasil evaluasi mereka menunjukkan bahwa produk atau jasa yang digunakan berkualitas. Persepsi pasien terhadap kualitas produk atau jasa dipengaruhi oleh dua hal yaitu kenyataan kualitas produk atau jasa dan komunikasi perusahaan. Menurut Garvin dalam Tjiptono (2007) kualitas produk dapat diukur dari (a). Kinerja (Performance) merupakan karakteristik operasi pokok dari produk inti (core product) yang dibeli. Misalnya kecepatan, kemudahan, dan kenyamanan dalam penggunaan; (b) Keistimewaan tambahan (Features), yaitu karakteristik sekunder atau pelengkap; (c). Daya tahan (Durability), yaitu ketahanan produk tersebut dapat digunakan.

2) Kualitas pelayanan, pasien akan merasa puas jika mereka memperoleh pelayanan yang baik atau sesuai dengan yang diharapkan. Parasuraman et al (2010) kualitas pelayanan dapat diukur dari keandalan (reliability), daya tanggap (responsiveness), jaminan (assurance), empati (emphaty),. prasarana (tangible),

3) Faktor emosional, pasien merasa bangga, puas dan kagum terhadap rumah sakit yang dipandang "rumah sakit mahal".

4) Harga, semakin mahal harga perawatan maka pasien mempunyai harapan yang lebih besar. Sedangkan rumah sakit yang berkualitas sama tetapi berharga murah, memberi nilai yang lebih tinggi pada pasien.

5) Biaya, pasien yang tidak perlu mengeluarkan biaya tambahan atau tidak perlu membuang waktu untuk mendapatkan jasa pelayanan, maka pasien cenderung puas terhadap jasa pelayanan tersebut. Biaya pelayanan, adalah biaya yang berisi biaya-biaya yang terkait dengan biaya pelayanan yang diberikan Dokter kepada pasien.

\section{Populasi dan Sampel}

\section{METODOLOGI PENELITIAN}

Dalam penelitian ini, adalah pasien BPJS rawat inap pada Rumah Sakit Umum Bina Kasih Medan bulan Juni- Juli 2019 sebanyak 1732 pasien.Sampel dalam penelitian ini pasien rawat inap sebayak 70 orang, $5 \times \mathrm{n}$ maka sampel sebanyak 5x14=70 orang Hair, at all, (1998)

\section{Metode Pengumpulan Data}

Metode pengumpulan data yang digunakan Angket atau Kuesioner, yaitu pengumpulan data yang dilakukan dengan cara membagikan angket kepada responden dengan mencantumkan beberapa alternatif jawaban dari pertanyaan yang disediakan dan setiap responden hanya boleh memilih salah satu alternatif jawaban yang paling tepat.

\section{Operasionalisi variabel}

Operasionalisasi variabel meliputi :

a. Kualitas jasa hal penting yang harus diusahakan oleh setiap perusahaan jika ingin yang dihasilkan dapat bersaing di pasar untuk memuaskan kebutuhan dan keinginan 
konsumen/pasien, dengan indikator 1.Kinerja(V1),2.Keistimewaan tambahan(V 2), 3. Daya tahan (V 3)

b. Kualitas Pelayanan, Segala bentuk aktivitas yang dilakukan oleh perusahaan guna memenuhi harapan konsumen/pasien, dengan indikator 1.Keandalan (V4), 2.Daya tanggap (V5), 3.Jaminan (V6),4.Empati (V7), 8.Prasarana (V8)

c. Faktor Emosional, suatu situasi dimana perasaan seseorang/pasien mengalami kepuasan atau ketidakpuasan terhadap apa yang dialami atau yang dirasakan dalam menggunakan produk/jasa,indikator 1.Gambaran Situasi (V9),2.Lingkungan sosial (V10), 3. Menguasai emosi (V11)

d. Harga, Semakin mahal harga perawatan maka pasien mempunyai harapan yang lebih besar. Sedangkan rumah sakit yang berkualitas sama tetapi berharga murah, memberi nilai yang lebih tinggi pada pasien, indikator, 1.Tingkat Harga (V12),2.Syarat Pembayaran (V13)

e. Biaya Pasien yang tidak perlu mengeluarkan biaya tambahan atau tidak perlu membuang waktu untuk mendapatkan jasa pelayanan, maka pasien cenderung puas terhadap jasa pelayanan tersebut, indikatorBiaya Pelayanan (V14)

\section{Tehnik analisis}

\section{a. Uji Validitas dan Reliabilitas Instrumen}

Valid berarti instrument tersebut dapat digunakan untuk mengukur apa yang seharusnya diukur, Sugiono (2008). Syarat minimum dianggap syarat kalau $r>0,30$ dikatakan valid dan korelasi kurang dari 0.30 dianggap tidak valid.

Uji reliabilitas adalah menguji apakah hasil kuesioner dapat dipercaya atau tidak, apabila $a>0,50$ artinya instrumen reliable dan $a<0,50$ artinya instrumen tidak reliable

\section{b. Analisis Faktor}

Teknik faktor merupakan suatu analisis statistik yang berfungsi untuk mereduksi atau meringkas beberapa variabel yang saling independent menjadi lebih sedikit. Dengan kata lain, proses analisis faktor mencoba menemukan hubungan antar sejumlah variabelvariabel yang saling independen satu dengan yang lain, sehingga dibuat satu atau beberapa kumpulan variabel yang sedikit demi sedikit dari jumlah variabel awal.

Analisis faktor terdapat beberapa tahapan dan uji yang harus diketahui, yaitu: Baroroh (2013), (1). Menganalisis faktor-faktor yang akan dianalisis, (2). Menguji faktor-faktor tersebut dengan menggunakan uji Bartlett Test of Spericiy dan Measure of Sampling Adequancy (MSA). (3).Proses factoring, (4). Proses rotasi, (5). Interpretasi penanaman faktor yang terbentuk.

Model dasar analisis faktor adalah data hasil observasi dari beberapa faktor $\left(f_{n}\right)$.

Secara matematis persamaanya adalah,

$$
X_{\text {in }}=\lambda_{1} f_{1}+\lambda_{2} f_{2}+\ldots .+\lambda_{n} f_{n}+e_{\text {in }}
$$

Keterangan: $X_{\text {in }}=$ Nilai dari variabel ke-i untuk observasi ke-n

$$
\begin{aligned}
& \mathrm{f}_{1}=\text { Faktor yang mempengaruhi produktivitas kerja karyawan } \\
& \lambda_{\mathrm{i}}=\text { Hubungan antar variabel }
\end{aligned}
$$

$\lambda_{\mathrm{ij}}$ yang biasa disebut factor loading, menunjukkan keterkaitan faktor dengan variabel yang diukur. Secara spesifik dapat dikatakan bahwa factor loading adalah korelasi antara faktor dengan variabel. Jika nilai KMO (Kaiser Meyer Olkin) Measure of Sampling Adeguarcy (MSA) lebih besar 0,50, maka kumpulan variabel tersebut dapat diproses lebih lanjut.

Angka pembatas (cut off point) agar sebuah variabel dapat secara nyata termasuk sebuah faktor adalah 0,50 . Jika sebuah faktor loadingnya $\geq 0,50$, maka variabel dapat dimasukkan sebagai suatu faktor. Jika hasil perhitungan faktor loadingnya $<0,50$, maka variabel tidak dapat dimasukkan dalam salah satu faktor manapun. Selanjutnya 
dilakukan analisis: (a).KMO (Kaiser Meyer Olkin) menunjukkan apakah sampel penelitian dapat diproses lebih lanjut. (b).Communalities menunjukkan nilai faktor yang menjelaskan varian masing-masing faktor. (c).Total variance expained menunjukkan nilai tiap variabel yang dianalisis. Penentuan jumlah faktor yang terbentuk didasarkan atas nilai eigenvalueslebih besar atau sama dengan satu.(d).Component matrix menunjukkan nilai korelasi antara suatu variabel dengan faktor yang terbentuk. (e).Rotated component matrix adalah memperjelas dan menegaskan variabel-variabel mana yang masuk ke dalam tiaptiap faktor. (f).Component transformation matrix menunjukkan adanya interkorelasi antara faktor yang terbentuk.

\section{ANALISIS DAN PEMBAHASAN}

a. Hasil uji validitas dan reabilitas

Tabel 1. Case Processing Summary

\begin{tabular}{|l|l|r|r|}
\hline \multicolumn{2}{|c|}{} & N & \multicolumn{1}{c|}{$\%$} \\
\hline Cases & Valid & 30 & UD 100,0 \\
\cline { 2 - 4 } & Excluded $^{a}$ & 0 &, 0 \\
\cline { 2 - 4 } & Total & 30 & 100,0 \\
\hline
\end{tabular}

Sumber: Hasil olahan data

Berdasarkan Tabel 1. di atas, terlihat bahwa jawaban 30 responden sudah valid. Hasil uji reliabilitas secara ditunjukkan pada tabel 1.3 berikut:

\section{Tabel 2. Reliability Statistics}

\begin{tabular}{|r|r|}
\hline \multicolumn{2}{|c|}{} \\
\hline Cronbach's Alpha & N of Items \\
\hline, 879 & 20 \\
\hline
\end{tabular}

Sumber: Hasil olahan data

Dari Tabel 2 diketahui bahwa nilai crombach's alpha sebesar 0,879. Artinya, dua puluh instrumen variabel penelitian sudah reliabel, karena nilai cronbach's alpha sebesar 0,879 $>0,50$.

b. KMO and Bartlett's Test

$K M O$ and Bartlett's Test berguna untuk mengetahui apakah variabel dan data penelitian dapat dianalisis lebih lanjut atau tidak. KMO and Bartlett's Test, ditumjukkan tabel 1.4. berikut:

Tabel 3. KMO and Bartlett's Test

\begin{tabular}{|l|l|r|}
\hline Kaiser-Meyer-Olkin Measure of Sampling Adequacy. &, 752 \\
\hline \multirow{2}{*}{$\begin{array}{l}\text { Bartlett's Test of } \\
\text { Sphericity }\end{array}$} & Approx. Chi-Square & 511,047 \\
\cline { 2 - 3 } & Df & 190 \\
\cline { 2 - 3 } & Sig. &, 000 \\
\hline
\end{tabular}

Sumber: Hasil olahan data

Berdasarkan Tabel 3 terlihat angka KMO (Kaiser-Meyer-Olkin) Measure of Sampling Adeguacy (MSA) adalah 0,752 dengan tingkat signifikansi 0,000. Oleh karena nilai KMO (Kaiser-Meyer-Olkin) sebesar 0,752 > 0,50 dan signifikan pada 5 persen, maka data hasil kuesioner layak dianalisis lebih lanjut dengan menggunakan analisis faktor.

c. Anti Image Correlatio

Anti image correlatio menunjukkan variabel mana yang dapat diproses lebih lanjut, dan variabel mana yang harus dikeluarkan sebagai variabel penelitian. Pada hasil Anti Image Matrices, di bagian Anti Image Correlation terlihat sejumlah angka yang membentuk diagonal yang menandakan besaran Measureof Sampling Adeguacy (MSA) masing-masing 
variabel. Dari hasil pengolahan, terlihat nilai MSA yang dilihat dari diagonalnya (bertanda a) adalah 0,627, 0,911, 0,805, 0,642, 0,737, 0,716, 0,734, 0,724, 0,723, 0,830, 0,685, $0,818,0,734,0,868,0,625,0,780,0,761,0,806,0,813$ dan 0,688 . Dari angka tersebut terlihat bahwa seluruh nilai MSA berada di atas 0,50, artinya variabel penelitian masih dapat diprediksi dan dianalisis lebih lanjut dengan mengikutkan seluruh faktor yang dominan mempengaruhi kepuasan pasien rawat inap pada Rumah Sakit Umum Bina Kasih Medan.

Tabel 4. Anti-image Matrices (Lanjutan)

\begin{tabular}{|l|l|r|l|l|r|}
\hline $\mathrm{V} 13.2$ & $\mathrm{~V} 13.3$ & $\mathrm{~V} 14$ & $\mathrm{~V} 13.2$ & $\mathrm{~V} 13.3$ & $\mathrm{~V} 14$ \\
\hline$-0,084$ & 0,114 & 0,002 & $-0,186$ & 0,254 & 0,005 \\
\hline$-0,014$ & $-0,052$ & 0,026 & $-0,030$ & $-0,114$ & 0,058 \\
\hline$-0,083$ & $-0,058$ & 0,079 & $-0,189$ & $-0,133$ & 0,186 \\
\hline$-0,158$ & $-0,045$ & 0,152 & $-0,397$ & $-0,115$ & 0,399 \\
\hline$-0,033$ & $-0,096$ & $-0,098$ & $-0,063$ & $-0,186$ & $-0,196$ \\
\hline 0,036 & $-0,042$ & $1-0,106$ & 0,074 & $-0,086$ & $-0,226$ \\
\hline$-0,100$ & 0,067 & 0,035 & $-0,193$ & 0,130 & 0,070 \\
\hline$-0,006$ & $-0,026$ & 0,085 & $-0,011$ & $-0,051$ & 0,171 \\
\hline 0,044 & $-0,034$ & 0,004 & 0,092 & $-0,072$ & 0,008 \\
\hline 0,000 & $-0,030$ & $-0,036$ & 0,000 & $-0,063$ & $-0,078$ \\
\hline$-0,093$ & $-0,140$ & 0,133 & $-0,201$ & $-0,305$ & 0,301 \\
\hline$-0,026$ & $-0,074$ & $-0,089$ & $-0,062$ & $-0,176$ & $-0,218$ \\
\hline 0,066 & $-0,090$ & $-0,064$ & 0,131 & $-0,180$ & $-0,133$ \\
\hline 0,050 & 0,045 & $-0,147$ & 0,125 & 0,113 & $-0,380$ \\
\hline$-0,100$ & $-0,136$ & 0,051 & $-0,205$ & $-0,280$ & 0,109 \\
\hline 0,027 & 0,099 & $-0,128$ & 0,066 & 0,248 & $-0,333$ \\
\hline 0,071 & $-0,001$ & 0,002 & 0,187 & $-0,002$ & 0,004 \\
\hline 0,410 & $-0,083$ & $-0,092$ &, $806 a$ & $-0,205$ & $-0,235$ \\
\hline$-0,083$ & 0,403 & $-0,079$ & $-0,205$ &, $813 a$ & $-0,202$ \\
\hline$-0,092$ & $-0,079$ & 0,377 & $-0,235$ & $-0,202$ &, $688 \mathrm{a}$ \\
\hline
\end{tabular}

a Measure of Sampling Adequacy (MSA)

Sumber: Hasil olahan data

a. Communalities

\section{PEMBAHASAN}

Communalities memberikan gambaran presentase keragaman suatu variabel yang dapat dijelaskan oleh faktor yang adalah yakni:

1. Variabel Kinerja, V1 angka 0,772, artinya variabel kinerja V1 dapat menjelaskan 77,2 persen varians yang terbentuk. Variabel kinerja, V1.2 angka 0,629, artinya variabel kinerja V1.2 dapat menjelaskan 62,9 persen varians yang terbentuk.

2. Variabel Keistimewaan tambahan, V2.1 angka 0,452, artinya variabel keistimewaan tambahan V2.1 dapat menjelaskan 45,2 persen varians yang terbentuk. Variabel Keistimewaan tambahan, V2.2 angka 0,690, artinya Variabel Keistimewaan tambahan V2.2 dapat menjelaskan 69 persen varians yang terbentuk.

3. Variabel Daya tahan, V3 angka 0,489 artinya variabel daya tahan V3 dapat menjelaskan 48,9 persen varians yang terbentuk.

4. Variabel Keandalan, V4 angka 0,587 artinya variabel keandalan V4 dapat menjelaskan 58,7 persen varians yang terbentuk. 
5. Variabel Daya tanggap, V5 angka 0,559 artinya variabel daya tanggap V5 dapat menjelaskan 55,9 persen varians yang terbentuk.

6. Variabel Jaminan, V6 angka 0,681 artinya variabel jaminan V6 dapat menjelaskan 68,1 persen varians yang terbentuk.

7. Variabel Empati, V7 angka 0,731 artinya variabel empati V7 dapat menjelaskan 73,1 persen varians yang terbentuk.

8. Variabel Prasarana, V8.1 angka 0,548 artinya variabel prasarana V8.1 dapat menjelaskan 54,8 persen varians yang terbentuk. Variabel Prasarana, V8.2 angka 0,740 artinya variabel prasarana V8.2 dapat menjelaskan 74 persen varians yang terbentuk.

9. Variabel Gambaran situasi, V9.1 angka 0,620 artinya variabel gambaran situasi V9.1 dapat menjelaskan 62 persen varians yang terbentuk. Variabel gambaran situasi, V9.2 angka 0,577 artinya variabel gambaran situasi V9.2 dapat menjelaskan 57,7 persen varians yang terbentuk.

10. Variabel Lingkungan Sosial, V10 angka 0,665 artinya variabel lingkungan sosial V10 dapat menjelaskan 66,5 persen varians yang terbentuk.

11. Variabel Menguasai emosi, V11 angka 0,488 artinya variabel menguasai emosi V11 dapat menjelaskan 48,8 persen varians yang terbentuk.

12. Variabel Tingkat harga, V12 angka 0,654 artinya variabel tingkat harga V12 dapat menjelaskan 65,4 persen varians yang terbentuk.

13. Variabel syarat pembayaran, V13.1 angka 0,642 artinya Variabel syarat pembayaran V13.1 dapat menjelaskan 64,2 persen varians yang terbentuk. Variabel syarat pembayaran ,V13.2 angka 0,712 artinya Variabel syarat pembayaran V13.2 dapat menjelaskan 71,2 persen varians yang terbentuk. Variabel syarat pembayaran,V13.3 angka 0,717 artinya Variabel syarat pembayaran V13.3 dapat menjelaskan 71,7 persen varians yang terbentuk.

14. Variabel Biaya pelayanan, V14 angka 0,771 artinya variabel biaya pelayanan V14 dapat menjelaskan 77,1 persen varians yang terbentuk.

15.

\section{b. Total Variance Explained}

Pada tabel total variance explained dan intial eigenvalue menunjukkan nilai eigenvalue untuk masing-masing faktor yang semula terdiri dari 20 indikator, seperti ditunjukkan pada tabel 5 berikut:

Tabel 5 Total Variance Explained

\begin{tabular}{|l|r|r|r|r|r|r|}
\hline \multirow{2}{*}{ Component } & \multicolumn{3}{|c|}{ Initial Eigenvalues } & \multicolumn{3}{|c|}{ Extraction Sums of Squared Loadings } \\
\cline { 2 - 7 } & Total & $\begin{array}{c}\text { \% of } \\
\text { Variance }\end{array}$ & $\begin{array}{c}\text { Cumulative } \\
\%\end{array}$ & Total & $\begin{array}{c}\text { \% of } \\
\text { Variance }\end{array}$ & Cumulative \% \\
\hline 1 & 6,503 & 32,517 & 32,517 & 6,503 & 32,517 & 32,517 \\
\hline 2 & 1,471 & 7,356 & 39,873 & 1,471 & 7,356 & 39,873 \\
\hline 3 & 1,340 & 6,699 & 46,571 & 1,340 & 6,699 & 46,571 \\
\hline 4 & 1,230 & 6,149 & 52,720 & 1,230 & 6,149 & 52,720 \\
\hline 5 & 1,159 & 5,797 & 58,517 & 1,159 & 5,797 & 58,517 \\
\hline 6 & 1,021 & 5,105 & 63,622 & 1,021 & 5,105 & 63,622 \\
\hline 7 &, 924 & 4,618 & 68,240 & & & \\
\hline 8 &, 867 & 4,333 & 72,573 & & & \\
\hline 9 &, 786 & 3,928 & 76,500 & & & \\
\hline 10 &, 759 & 3,795 & 80,295 & & & \\
\hline 11 &, 688 & 3,440 & 83,735 & & & \\
\hline 12 &, 672 & 3,360 & 87,095 & & & \\
\hline 13 &, 532 & 2,658 & 89,753 & & & \\
\hline \hline
\end{tabular}

Faktor-Faktor Yang Dominan Mempengaruhi Kepuasan Pasien Rawat Inap Pada Rumah Sakit 
Volume 21 Nomor 1, Maret 2021

\begin{tabular}{|l|r|r|r|r|r|r|}
\hline \multirow{2}{*}{ Component } & \multicolumn{3}{|c|}{ Initial Eigenvalues } & \multicolumn{3}{|c|}{ Extraction Sums of Squared Loadings } \\
\cline { 2 - 7 } & Total & $\begin{array}{r}\% \text { of } \\
\text { Variance }\end{array}$ & $\begin{array}{c}\text { Cumulative } \\
\%\end{array}$ & Total & $\begin{array}{c}\% \text { of } \\
\text { Variance }\end{array}$ & Cumulative \% \\
\hline 14 &, 447 & 2,234 & 91,988 & & & \\
\hline 15 &, 401 & 2,006 & 93,994 & & & \\
\hline 16 &, 370 & 1,852 & 95,846 & & & \\
\hline 17 &, 267 & 1,334 & 97,180 & & & \\
\hline 18 &, 221 & 1,106 & 98,286 & & & \\
\hline 19 &, 198 &, 989 & 99,274 & & & \\
\hline 20 &, 145 &, 726 & 100,000 & & & \\
\hline
\end{tabular}

Extraction Method: Principal Component Analysis

Sumber: Hasil olahan data

Susunan eigenvalues selalu diurutkan dari yang terbesar sampai terkecil, dengan kriteria bahwa angka eigenvalues di bawah 1 tidak digunakan dalam menghitung jumlah faktor yang terbentuk. Jika 20 indikator tersebut diringkas menjadi satu faktor, maka varians yang dapat dijelaskan oleh satu faktor tersebut, sebagai berikut:
a. Varians faktor pertama adalah $6,503: 20 \times 100 \%=32,517$ persen
b. Varians faktor kedua adalah 1,471: $20 \times 100 \%=7,356$ persen
c. Varians faktor ketiga adalah $1,340: 20 \times 100 \%=6,699$ persen
d. Varians faktor keempat adalah 1,230:20 x 100\% $=6,149$ persen
e. Varians faktor kelima adalah 1,159:20 x 100\% $=5,797$ persen
f. Varians faktor keenam adalah $1,021: 20 \times 100 \%=\underline{5,105}$ persen +
Total varians
63,622 persen

Eigenvalues menunjukkan kepentingan relative masing-masing faktor dalam menghitungvarians 20 variabel yang dianalisis. Jumlah angka eigenvalues untuk 43 indikator variabel adalah $(6,503+1,471+1,340+1,230+1,159+1,021+0,924+0,867+0,786+0,759+$ $0,688+0,672+0,532+0,447+0,401+0,370+0,267+0,221+0,198+0,145)=20$. Nilai eigenvalue yang lebih besar dari satu terdiri dari 6 variabel, sehingga 20 variabel dijadikan menjadi 6 variabel yang secara bersama dapat menjelaskan varians total sebesar 63,622 persen.

\section{c. Component Matrix}

Component matrix yaitu besar korelasi antara tiap variabel dengan variabel 1 , variabel 2,variabel 3, variabel 4, variabel 5, variabel 6. Penentuan variabel dari masing-masing faktor dilakukan dengan membandingkan besaran korelasi pada setiap baris. Component matrix ditunjukkan pada tabel 110. berikut :

Tabel 6. Component matrix (a)

\begin{tabular}{|l|r|r|r|r|r|r|}
\hline & \multicolumn{7}{|c|}{ Component } \\
\cline { 2 - 7 } & 1 & \multicolumn{1}{|c|}{2} & 3 & \multicolumn{1}{c|}{4} & \multicolumn{1}{l|}{5} & \multicolumn{1}{c|}{6} \\
\hline V1 &, 463 &, 416 &, 017 &, 496 &,- 294 &, 226 \\
\hline V1.2 &, 657 &,- 154 &, 199 &, 350 &,- 108 &, 037 \\
\hline V2.1 &, 624 &,- 108 &, 131 &,- 146 &,- 097 &,- 057 \\
\hline V2.2 &, 569 &, 466 &, 328 &, 059 &, 053 &, 185 \\
\hline V3 &, 447 &, 380 &,- 088 &, 137 &,- 111 &,- 325 \\
\hline V4 &, 481 &,- 464 &,- 178 &, 229 &, 099 &, 215 \\
\hline V5 &, 422 &, 183 &, 334 &,- 364 &, 182 &,- 264 \\
\hline V6 &, 469 &,- 165 &, 294 &, 007 &, 123 &, 576 \\
\hline V7 &, 498 &,- 311 &, 387 &, 117 &,- 446 &,- 153 \\
\hline V8.1 &, 609 &,- 066 &, 172 &, 049 &, 029 &,- 374 \\
\hline
\end{tabular}

Faktor-Faktor Yang Dominan Mempengaruhi Kepuasan Pasien Rawat Inap Pada Rumah Sakit 
Volume 21 Nomor 1, Maret 2021

\begin{tabular}{|l|r|r|r|r|r|r|}
\hline & \multicolumn{7}{|c|}{ Component } \\
\cline { 2 - 7 } & 1 & 2 & 3 & \multicolumn{1}{c|}{4} & \multicolumn{1}{c|}{5} & \multicolumn{1}{c|}{6} \\
\hline V8.2 &, 392 &,- 453 &,- 011 &, 384 &, 430 &,- 220 \\
\hline V9.1 &, 656 &, 109 &,- 153 &,- 320 &,- 047 &, 222 \\
\hline V9.2 &, 493 &, 002 &, 143 &,- 304 &, 432 &, 184 \\
\hline V10 &, 734 &,- 162 &,- 046 &,- 083 &,- 288 &,- 090 \\
\hline V11 &, 460 &, 245 &,- 456 &, 031 &, 073 &, 040 \\
\hline V12 &, 651 &,- 187 &,- 269 &,- 204 &,- 215 &, 185 \\
\hline V13.1 &, 690 &, 031 &, 223 &,- 323 &,- 038 &,- 099 \\
\hline V13.2 &, 643 &, 408 &,- 157 &, 246 &, 214 &,- 029 \\
\hline V13.3 &, 685 &,- 026 &,- 192 &, 104 &, 421 &,- 147 \\
\hline V14 &, 578 &,- 128 &,- 566 &,- 221 &,- 215 &,- 081 \\
\hline
\end{tabular}

Sumber : Hasil olahan data

Dari tabel 6 diatas, dapat dijelaskan arti dari component matrix.

1. Variabel kinerja (F1), V1 korelasi antara indikator sebesar 0,496<0,50, sehingga tidak dapat di masukkan ke dalam faktor manapun. V1.2 korelasi antara indikator sebesar $0,657>0,50$ sehingga dapat dimasukkan ke dalam faktor manapun.

2. Variabel keistimewaan tambahan (F2), V2.1 korelasi antara indikator sebesar $0,624>0,50$, sehingga dapat di masukkan ke dalam faktor manapun. V2.2 korelasi antara indikator sebesar 0,569 > 0,50 sehingga dapat dimasukkan ke dalam faktor manapun.

3. Variabel daya tahan (F3), V3 korelasi antara indikator sebesar 0,447< 0,50, sehingga tidak dapat di masukkan ke dalam faktor manapun.

4. Variabel keandalan (F4), V4 korelasi antara indikator sebesar 0,481 < 0,50 sehingga tidak dapat dimasukkan ke dalam faktor manapun.

5. Variabel daya tanggap (F5), V5 korelasi antara indikator sebesar 0,422 < 0,50 sehingga tidak dapat dimasukkan ke dalam faktor manapun.

6. Variabel jaminan (F6), V6 korelasi antara indikator sebesar $0,576>0,50$, sehingga dapat di masukkan ke dalam faktor manapun.

7. Variabel empati (F7), V7 korelasi antara indikator sebesar 0,498 $<0,50$, sehingga tidak dapat di masukkan ke dalam faktor manapun.

8. Variabel prasarana (F8), V8.1 korelasi antara indikator sebesar 0,609 > 0,50 sehingga dapat dimasukkan ke dalam faktor manapun. V8.2 korelasi antara indikator sebesar 0,430 $<0,50$ sehingga tidak dapat dimasukkan ke dalam faktor manapun.

9. Variabel gambaran situasi (F9), V9.1 korelasi antara indikator sebesar 0,656 $>0,50$ sehingga dapat dimasukkan ke dalam faktor manapun. V9.2 korelasi antara indikator sebesar 0,493 < 0,50 sehingga tidak dapat dimasukkan ke dalam faktor manapun.

10. Variabel lingkungan sosial (F10), V10 korelasi antara indikator sebesar 0,734 > 0,50, sehingga dapat di masukkan ke dalam faktor manapun.

11. Variabel menguasai emosi (F11), V11 korelasi antara indikator sebesar 0,460<0,50, sehingga tidak dapat di masukkan ke dalam faktor manapun.

12. Variabel tingkat harga (F12), V12 korelasi antara indikator sebesar $0,651>0,50$ sehingga dapat dimasukkan ke dalam faktor manapun.

13. Variabel syarat pembayaran (F13), V13.1 korelasi antara indikator sebesar 0,690>0,50 sehingga dapat dimasukkan ke dalam faktor manapun. V13.2 korelasi antara indikator sebesar 0,643 > 0,50, sehingga dapat di masukkan ke dalam faktor manapun. V13.3 korelasi antara indikator sebesar 0,685 > 0,50, sehingga dapat di masukkan ke dalam faktor manapun. 
14. Variabel biaya pelayanan (F14), V14 korelasi antara indikator sebesar 0,578 $>0,50$ sehingga dapat dimasukkan ke dalam faktor manapun.

\section{d. Rotated component matrix}

Rotated component matrix berguna untuk memperjelas variabel-variabel mana yang masuk ke dalam tiap-tiap faktor. Suatu variabel dapat dimasukkan ke dalam suatu faktor jika nilai korelasinya lebih besar dari 0,50. Banyak sekali faktor loading yang berubah setelah dilakukan proses rotasi, ada yang faktor loading nya menjadi lebih kecil atau lebih besar. Hasil analisis rotated component matrix ditunjukkan pada tabel 7 berikut:

Tabel 7 Rotated Component Matrix

\begin{tabular}{|c|c|c|c|c|c|c|}
\hline & \multicolumn{6}{|c|}{ Component } \\
\hline & 1 & 2 & 3 & 4 & 5 & 6 \\
\hline V1 & ,092 & ,793 &,- 161 & ,272 &,- 049 & 180 \\
\hline V1.2 & ,128 & ,353 & ,072 & ,545 & ,348 & ,256 \\
\hline V2.1 & 327 & 112 & IUD,365 & ,401 & ,131 & , 148 \\
\hline V2.2 & ,000 &, 611 & 425 &, 148 &,- 065 & ,330 \\
\hline V3 & ,189 &, 532 & ,228 & 166 & ,064 &,- 295 \\
\hline $\mathrm{V4}$ & 350 & ,008 &,- 144 & ,222 & ,522 & ,350 \\
\hline V5 & ,030 & ,084 & ,730 & ,133 & P., 014 &,- 017 \\
\hline V6 & ,098 & 105 & ,149 & 188 & ,124 & 767 \\
\hline V7 & , 084 & , 044 & ,113 & 835 & ,073 & ,079 \\
\hline V8.1 & ,143 & ,206 & ,417 & 426 & ,343 &,- 111 \\
\hline V8.2 &,- 006 & ,001 & ,056 & 177 & ,838 & ,051 \\
\hline V9.1 &, 598 & 226 & 348 & ,076 & ${ }_{-}-, 032$ & ,288 \\
\hline V9.2 & ,189 & ,041 &, 556 &,- 102 & $5 \quad, 222$ & 413 \\
\hline V10 & ,535 & , 170 & 227 & ,523 & S, 143 & ,064 \\
\hline V11 & 505 & ,418 & ,065 &,- 165 & ,165 &,- 024 \\
\hline V12 & ,708 & $>079$ & ,106 & 266 & ,084 & 238 \\
\hline V13.1 & ,327 &, 139 & 605 & $A \quad, 357$ & ,039 & ,146 \\
\hline V13.2 & ,248 & 700 & 101,256 &,- 043 & ,302 & ,046 \\
\hline V13.3 & ,338 & 311 & ,350 &,- 012 & ,616 & ,059 \\
\hline V14 & 844 & ,079 & ,056 & 131 & 139 & -117 \\
\hline
\end{tabular}

Sumber Hasil olahan data

Dari tabel 7 di atas, disajikan arti rotated component matrix sebagai berikut:

1. Nilai korelasi variabel kinerja, V1.1 dengan indikator 2 sebelum rotasi sebesar 0,496, setelah rotasi diperbesar menjadi 0,793 , sehingga dapat dimasukkan sebagai indikator 2. V1.2 dengan indikator 4 sebelum rotasi sebesar 0,657 , setelah rotasi diperbesar menjadi 0,545, sehingga dapat dimasukkan sebagai indikator 4 .

2. Nilai korelasi variabel keistimewaan tambahan, V2.1 dengan indikator 4 sebelum rotasi sebesar 0,624, setelah rotasi diperbesar menjadi 0,401<0,50, sehingga tidak dapat dimasukkan sebagai indikator 4. V2.2 dengan indikator 2 sebelum rotasi sebesar 0,569, setelah rotasi diperbesar menjadi 0,611 , sehingga dapat dimasukkan sebagai indikator 2.

3. Nilai korelasi variabel daya tahan, V3 dengan indikator 2 sebelum rotasi sebesar 0,447 , setelah rotasi diperbesar menjadi 0,532 , sehingga dapat dimasukkan sebagai indikator 2 . 
4. Nilai korelasi variabel keandalan, V4 dengan indikator 5 sebelum rotasi sebesar 0,481, setelah rotasi diperbesar menjadi 0,522 , sehingga dapat dimasukkan sebagai indikator 5 .

5. Nilai korelasi variabel daya tanggap, V5 dengan indikator 3 sebelum rotasi sebesar 0,422 , setelah rotasi diperbesar menjadi 0,730 , sehingga dapat dimasukkan sebagai indikator 3.

6. Nilai korelasi variabel jaminan, V6 dengan indikator 6 sebelum rotasi sebesar 0,576, setelah rotasi diperbesar menjadi 0,767 , sehingga dapat dimasukkan sebagai indikator 6.

7. Nilai korelasi variabel empati, V7 dengan indikator 4 sebelum rotasi sebesar 0,498 , setelah rotasi diperbesar menjadi 0,835 , sehingga dapat dimasukkan sebagai indikator 4.

8. Nilai korelasi variabel prasarana, V8.1 dengan indikator 4 sebelum rotasi sebesar 0,609, setelah rotasi diperbesar menjadi $0,426<0,50$, sehingga tidak dapat dimasukkan sebagai indikator manapun. V8.2 dengan indikator 5 sebelum rotasi sebesar 0,430, setelah rotasi diperbesar menjadi 0,838 , sehingga dapat dimasukkan sebagai indikator 5 .

9. Nilai korelasi variabel gambaran situasi, V9.1 dengan indikator 1 sebelum rotasi sebesar 0,656, setelah rotasi diperbesar menjadi 0,598, sehingga dapat dimasukkan sebagai indikator 1 . V9.2 dengan indikator 3 sebelum rotasi sebesar 0,493 , setelah rotasi diperbesar menjadi 0,556, sehingga dapat dimasukkan sebagai indikator 3 .

10. Nilai korelasi variabel lingkungan sosial, V10 dengan indikator 1 sebelum rotasi sebesar 0,734 setelah rotasi diperbesar menjadi 0,535, sehingga dapat dimasukkan sebagai indikator 1 .

11. Nilai korelasi variabel menguasai emosi, V11 dengan indikator 1 sebelum rotasi sebesar 0,460 , setelah rotasi diperbesar menjadi 0,505 , sehingga dapat dimasukkan sebagai indikator 1.

12. Nilai korelasi variabel tingkat harga, V12 dengan indikator 1 sebelum rotasi sebesar 0,651 setelah rotasi diperbesar menjadi 0,708, sehingga dapat dimasukkan sebagai indikator 1.

13. Nilai korelasi variabel syarat pembayaran, V13.1 dengan indikator 3 sebelum rotasi sebesar 0,690, setelah rotasi diperbesar menjadi 0,605, sehingga dapat dimasukkan sebagai indikator 3. V13.2 dengan indikator 2 sebelum rotasi sebesar 0,643 setelah rotasi diperbesar menjadi 0,700, sehingga dapat dimasukkan sebagai indikator 2. V13.3 dengan indikator 5 sebelum rotasi sebesar 0,685, setelah rotasi diperbesar menjadi 0,616, sehingga dapat dimasukkan sebagai indikator 5 .

14. Nillai korelasi variabel biaya produk, V14 dengan indikator 1 sebelum rotasi sebesar 0,578 setelah rotasi diperbesar menjadi 0,844 , sehingga dapat dimasukkan sebagai indikator 1 .

Berdasarkan uraian diatas tersebut, dapat diringkas faktor-faktor yang mempengaruhi kepuasan pasien rawat inap pada Rumah Sakit Umum Bina Kasih Medan, yang ditunjukkan pada tabel 8 berikut:

Tabel 8. Faktor-faktor yang mempengaruhi kepuasan pasien rawat inap pada Rumah Sakit Umum Bina Kasih Medan.

\begin{tabular}{|l|l|l|l|}
\hline Simbol & Korelasi & Indikator & Keterangan \\
\hline V9 (V91) & 0,598 & 1 & Gambaran situasi \\
V10(V10) & 0,535 & 1 & Lingkungan sosial \\
\hline
\end{tabular}

Faktor-Faktor Yang Dominan Mempengaruhi Kepuasan Pasien Rawat Inap Pada Rumah Sakit 
Volume 21 Nomor 1, Maret 2021

\begin{tabular}{|l|l|l|l|}
\hline V11(V11) & 0,505 & 1 & Menguasai emosi \\
V12 (V12) & 0,708 & 1 & Tingkat harga \\
V14(V14) & 0,844 & 1 & Biaya produk \\
\hline V1 (V1.1) & 0,793 & 2 & Kinerja \\
V2 (V2.2) & 0,611 & 2 & Kinerja \\
V3 (V3) & 0,532 & 2 & Daya tahan \\
V13 (V13.2) & 0,700 & 2 & Syarat pembayaran \\
\hline V5 (V5) & 0,730 & 3 & Daya tanggap \\
V9 (V9.2) & 0,556 & 3 & Gambaran situasi \\
V13 (V13.1) & 0,605 & 3 & Syarat pembayaran \\
\hline V1 (V1.2) & 0,545 & 4 & Kinerja \\
V7 (V7) & 0,835 & 4 & Empati \\
\hline V4 (V4) & 0,522 & 5 & Keandalan \\
V13 (V13.3) & 0,616 & 5 & Syarat pembayaran \\
\hline V6 (V6) & 0,767 & 6 JUDI & Jaminan \\
\hline
\end{tabular}

Sumber : Hasil olahan data

e. Component Transformation Matrix

Hasil Component Transformation Matrix ditunjukkan pada tabel 1.13 berikut ini

Tabel 9 Component Transformation Matrix

\begin{tabular}{|c|c|c|c|c|c|c|}
\hline $\begin{array}{c}\text { Compo } \\
\text { nent }\end{array}$ & 1 & 2 & 3 & 4 & 5 & 6 \\
\hline 1 &, 530 &, 436 &, 432 &, 408 &, 341 &, 246 \\
\hline 2 &,- 127 &, 730 &, 245 &,- 374 &,- 469 &,- 179 \\
\hline 3 &,- 696 &,- 052 &, 418 &, 465 &,- 163 &, 310 \\
\hline 4 &,- 379 &, 517 &,- 587 &, 192 &,- 455 &,- 021 \\
\hline 5 &,- 251 &,- 055 &, 373 &,- 627 &, 607 &, 184 \\
\hline 6 &, 115 &, 068 &,- 309 &,- 218 &,- 249 &, 882 \\
\hline
\end{tabular}

Sumber: Hasil Olahan Data

Berdasarkan tabel 9, terlihat bahwa pada diagonal variabel (component) 1 berada di angka 0,530 . Untuk component 2 berada di angka 0,730 . Untuk component 3 berada di angka 0,465 . Untuk component 4 berada di angka 0,517. Untuk component 5 berada di angka 0,607. Untuk component 6 berada di angka 0,882. Hal ini yang menunjukkan bahwa 6variabel (component) yang terbentuk sudah tepat, karena mempunyai nilai korelasi yang tinggi.

\section{f. Faktor Yang Paling Dominan Mempengaruhi Kepuasan Pasien Rawat Inap}

Faktor yang dominan mempengaruhi kepuasan pasien rawaat inap pada Rumah Sakit Umum Bina Kasih Medan adalah faktor biaya produk (F5) dengan nilai korelasi sebesar 0,844, faktor empati (F2) dengan nilai korelasi sebesar 0,835, faktor kinerja (F1) dengan nilai korelasi sebesar 0,793, faktor tingkat harga (F4) dengan nilai korelasi sebesar 0,708. Dilihat dari nilai koefisien korelasinya, diketahui bahwa faktor yang paling dominan mempengaruhi kepuasan pasien rawaat inap pada Rumah Sakit Umum Bina Kasih Medan adalah faktor biaya pelayanan.

\section{KESIMPULAN}

Faktor yang paling dominan mempengaruhi kepuasan pasien rawat inap pada Rumah Sakit Umum Bina Kasih Medan adalah faktor biaya pelayanan, faktor empati, faktor kinerja, faktor tingkat harga. Dilihat dari nilai koefisien korelasinya, diketahui bahwa faktor 
biaya pelayanan merupakan faktor yang paling dominan mempengaruhi kepuasan pasien rawat inap pada Rumah Sakit Umum Bina Kasih Medan, sehingga untuk meningkatkan kepuasan pasien diharapkan pihak manajemen Rumah Sakit memperhatikan dan menjelaskan kepada pasien segala jenis biaya pelayanan atau biaya tambahan (biaya saat dokter melakukan visit, biaya obat untuk kesembuhan pasien) dalam menangani keluhan pasien.

\section{DAFTAR PUSTAKA}

Arikunto. R. Lcrbin,2006. Kepuaan Pclanggan. Pengukuran dan Penganalisaan Dengan SPSS, Edisi Pcrtama, Pcncrbit: Gramedia Pustaka Umum, Jakarta.

Craven, D.W. 2000. Pemasaran Strategis, (terjemahan). Jakarta: Penerbit Erlangga.

Hair, J.F., Anderson, R.E., Tatham, R.L., dan Black, W.C. 1998. Multivariate Data Analisys. Pearson Prentice Hall.

Irsansyah Putra , P. Bhuana Katili dan F. Arina, 2013. Pengaruh Kualitas Pelayanan Terhadap Persepsi Dan Kepuasan Pasien dalam Meningkatkan Loyalitas Jurnal Teknik Industri Universitas Sultan Ageng Tirtayasa, Vol.1, No.1, Maret 2013, pp.41-47 ISSN 2302-495X Kotler. Philip. 2002. Manajemen Pemasaran Penerbit: Erlangga, Jakarta.

Kotler, Philip dan Gary Armstong. 2008. Perinsip-Perinsip Pemasaran.Edisi ke 12 Jakarta: Pernerbit Erlangga.

Kristanto, Paulus Lilik. 2011 . Psikologi Pemasaran Yogyakarta CAPS.

Lupiyoadi Rambar,2007. Manajemen Pemasaran Jasa Teori dan Praktik Edisi Pertama, Cetakan Pertama, Penerbit : Salemba Empat Jakarta. 2001. Manajemen Pemasaran Jasa Teori dan Praktik. Salemba Empat, Jakarta.

Nilaikan, Nindia 2012. Faktor-faktor Yang Mempengaruhi Kcpuasan Pelanyanan Kesehatan Pada Pasien Rawat Inap di RSUD Sukoharjo, Skripsi University Sebelas Maret Surakarta

Nooria, Widoningsih. 2008. Pengaruh Persepsi Kualitas Jasa Pelayanan Terhadap Kepuasan dan Loyalitas Pelanggan di RSU Saras Husada Purworejo. Surakarta : Fakultas Psikologi Universitas Muhammadiyah Surakarta.

Nirsetyo Wahdi 2006. Analisis faktir-faktor yang mempengaruhi kepuasan pasien sebagai upaya peningkatan loyalitas pasien (Studi empiris pada rumah sakit Panti Wilasa Ciatarum Sermarang ), Thesis Universitas Diponegoro Semarang

Parasuraman. A., Berry, Leonard L. and Zeithml. Valaria A 2010 . Reassessment of Expectations as a Comparison Standar in Measuring Serv ice Quality: Implication for future Research.. Journal of Marketing. Vol. 58 (January ). PP 111- 124.

Rangkuti, Freddy 2002.Measuring Costumer Satifaction, Penerbit PT Gramedia Pustaka Utama, Jakarta.

Satrianegara, Fais \& Siti Saleha,2009. Buku Ajar Organisasi dan Manajemen Pelayanan Kesehatan serta Kcbidanan. Jakarta Salemba Mcdika

Sugiyono, 2009. Metode Penelitian Kuantitatif, Kualitatif dan RED, Bandung : Alfabeta.

Tjiptono, Fandi. 2007. Strategi Panasaran. Edisi Kedua Yogyakarta : Andi

Widi l.cstari, Martini 2015. Analisis Faktor-faktor Yang Mcmpcngaruhi Kcpuasan Rawat Inap di RSUD Kabupaten Baleleng, Sknpsi Universitas Pcndidikan Ganesha Singaraja Indonesia.

Yamit, Zulian. 2005. Manajemen Kualitas Produk dan Jasa. Edisi Pertama. Yogyakarta: Penerbit Ekonisia Kampus 